\author{
Research Article \\ www.ijrap.net (ISSN:2229-3566)
}

UBLSHING HOUSE

whwijrap.net(ISSN:2229-3566)

\title{
ANALYSIS OF PANCHAMAHABHOOTA SIDDHANTA WITH SPECIAL REFERENCE TO AMAVATA AND ITS MANAGEMENT THROUGH ERANDAMOOLADI NIRUHA BASTI: A CLINICAL STUDY
}

\author{
Parinita S G ${ }^{1 *}$, J. R Joshi ${ }^{2}$, Sandeep Desai ${ }^{3}$ \\ ${ }^{1}$ P. G. Scholar, Department of Samhita and Siddhanta, Ayurveda Mahavidyalaya Hubli, Karnataka, India \\ ${ }^{2}$ Professor and HOD, Department of Samhita and Siddhanta, Ayurveda Mahavidyalaya Hubli, Karnataka, India \\ ${ }^{3}$ Assistant Professor, Department of Samhita and Siddhanta, Ayurveda Mahavidyalaya Hubli, Karnataka, India
}

Received on: 03/10/19Accepted on: 30/11/19

\author{
*Corresponding author \\ E-mail: parinitag42@gmail.com
}

DOI: $10.7897 / 2277-4343.110112$

\begin{abstract}
Ayurveda has taken the foremost place in the management of crippling diseases. Amavata is one of them. With the march of time, most of the dietary habits, social structure, lifestyle and environment have been changing. Occurrence of Amavata kind of diseases on large scale is one of the outcomes of this modification. From modern point of view, this disease looks similar to Rheumatoid Arthritis in its clinical appearance. It is commonest among the chronic inflammatory joint disease in which joints become swollen, painful and stiff. Drugs that are available in modern science like NSAIDs have gastro-intestinal side effects whereas; DMARDs have renal and hepatic suppression. Hence considering the unpleasant effects of the disease and failure of complete cure through modern medicine, the present single arm study was undertaken with the objectives as to analyze the role of Panchamahabhoota in the manifestation of Amavata and to find out the efficacy of Erandamooladi niruha basti on the basis of Panchamahabhoota and assess its clinical and statistical significance with $5 \%$ level of significance.
\end{abstract}

Keywords: Amavata, Panchamahabhoota, Rheumatoid Arthritis, Erandamooladi niruha basti

\section{INTRODUCTION}

Ayurveda, the ancient system of medicine which originated thousands of years before, is a treasure of outputs and data obtained through invasive research program. Based on many remarkable theories, the science has maintained its unique protocol to make the world healthy and happy as well. Amavata is one of the major diseases in the present era, which is mainly induced due to uncontrolled habits developed gradually in society. It was described as a separate disease with its Nidana Panchaka in detail by Acharya Madhava who belonged to the medieval period. A separate chapter on its behalf was explained by Acharya. ${ }^{1}$ From the modern point of view, this disease can be more or less compared to Rheumatoid arthritis based on its clinical appearance. "Sarvam dravyam Panchabhoutikam" i.e., all the dravyas existing in the world are made up of Panchamahabhoota and normal physiology, pathology is dependent on the variation in the constitution of these mahabhootas. Panchamahabhoota Siddhanata is more important than any other Siddhantas because, it includes everything into it. For example, the main constituents of the body - Tridosha, Saptadhatu, Trimala etc are all Panchabhoutika ${ }^{2,} 3$. Panchamahabhoota is able to provide ultimate solution for the doubts in the field of Ayurveda. Basti is said to be the most important constituent of the Panchakarma due to its multiple effects. ${ }^{4}$ The prime cause for the causation of so many diseases, the Vata is being treated efficiently well by Basti ${ }^{5}$. So, in the present study, Basti has been selected as Shodhana procedure. Since Panchamahabhoota is related to both the disease and the treatment, an attempt has been made to establish this relation through this study.

\section{MATERIAL AND METHODS}

30 subjects suffering from Amavata, fulfilling the diagnostic and inclusion criteria belonging to either gender, irrespective of socioeconomic status or caste were selected for the clinical study. All the 30 subjects were taken under single group and were treated with Erandamooladi niruha basti for 16 days. Study was approved by institutional ethical committee on 13 April 2019. The results were then subjected to statistical analysis.

Analysis of Panchamahabhoota siddhanta in the manifestation of Amavata

It is a well-known fact that Ayurveda is the life science, which is based on the philosophical thoughts and facts, which very much exist in each of the things in this universe. It is the medical science which is brought down directly from the celestial city. Since it is believed to be the knowledge documented directly by Lord Brahma $^{6}$, the Creator himself, it can be proclaimed that this science is based on the philosophical, practical and logical happenings in and around the world. It establishes the fact of Loka Purusha samya, which means whatever is present in universe is present in our body and vice versa. One of the basic and prime factors which exist in common between the individual and the universe is Panchamahabhoota.

In the present study, an attempt has been made in relating to the Nidana, Lakshana and Samprapti of Amavata and its management to Panchamahabhootas and justifies the proven fact, i.e. Sarvam dravyam Panchabhoutikam. 


\section{Nidanas}

Aharaja nidanas like Viruddhahara- E.g. Consumption of curd during night, consumption of Fruit salad with Ice cream/ banana along with milk, drinking water every day in the morning, consuming cold water after exhaustion, Guru, Abhishyandi Bhojana, Ati Madhura Bhojana and Viharaja nidanas like Viruddhachesta- E.g. Ratri Jagarana, Divaswapna, Sitting / Sleeping in uncomfortable postures; Avyayama; Ativyavaya; Snigdha bhojana anantara vyayama and Nishchalatva and Manasika nidanas like Chinta, Shokha, Bhaya etc are all mainly of Prithvi, Jala and Vayu mahabhoota pradhana (because all are of Kahpa and Vata dominant $)^{7}$

\section{Lakshanas}

The pratyatma lakshanas of Amavata- Angamarda, Aruchi, Trishna, Alasya, Gourava, Jwara, Angashoonata etc are mainly of tridosha with the dominance of Vata and Kapha. From this, we can interpret that the lakshanas are with the predominance of Prithvi, Vayu, Jala and Akasha Mahabhoota. ${ }^{8}$

\section{Samprapti}

- In the Samprapti of Amavata, the dooshita Ama is mainly of Prithvi and Jala mahabhoota pradhana.

- Prakupita Vata is of Vayu and Akasha mahabhoota pradhana. ${ }^{9}$

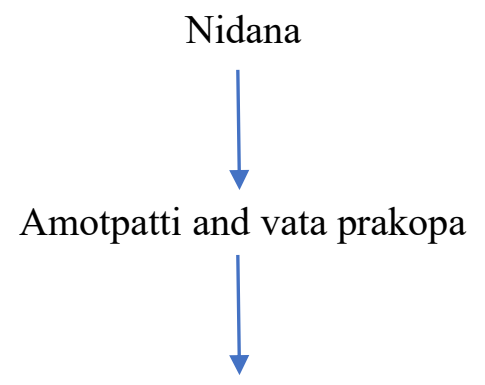

Ama with the help of vyana vata travel to the sira hridaya and kantha pradesha

There it gets more vitiated by the vatadi doshas and travel through the dhamani leading to nana varna and ati picchila anna rasa(ama)

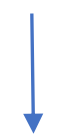

This leads to sroto abhishyandha

Vitiated vata and kapha along with ama together gets more vitiated and lodges in shleshma sthana- Dosha (Ama, Vyana Vata and Shleshaka Kapha) - dushya (Rasa Asthi Sandhi) sammoorchana

Causes severe pain in trika pradesha, sandhi and koshta leading to stabdhata of angapratyanga

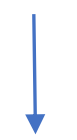

\section{$\underline{\text { Amavata }}$}




\section{Chikitsa}

Chakradatta was the one to describe in detail, the chikitsa sootra for Amavata. According to him

\section{Laganam swedanam tiktam deepanani katooni cha | Virechanam snehapanam bastayachamamarute ||}

Among which Basti was mainly selected for the study. Erandamooladi Niruha Basti in the schedule of Kala Basti, was adopted with Brihat Saindhavadhi Taila for Sneha Basti. Considering the properties of the individual drugs of Brihat Sandhavadi Taila, the Taila in general is formed with the predominance of Agni, Vayu and Akasha Mahabhoota and considering the constituents of each of the Drugs of Erandamooladi Niruha Basti, it can be said that it is formed with the predominance of Agni, Vayu and Prithvi Mahabhoota. ${ }^{10}$

\section{Observations}

In the present study on Amavata, 30 subjects fulfilling the criteria were incidentally and randomly selected. General Observations like Age, Gender etc. as well as Observations related to the disease were recorded and are given hence forth.

Table 1: Age wise distribution

\begin{tabular}{|c|c|c|}
\hline \multirow{2}{*}{ Age in Years } & \multicolumn{2}{|c|}{ Trial Group } \\
\cline { 2 - 3 } & No. of Subjects & Percentage (\%) \\
\hline $\mathbf{2 1}$ to 30 & 4 & 13.33 \\
\hline $\mathbf{3 1}$ to 40 & 19 & 63.33 \\
\hline $\mathbf{4 1}$ to 50 & 5 & 16.66 \\
\hline $\mathbf{5 1}$ to 60 & 2 & 6.66 \\
\hline
\end{tabular}

Table 2: Gender wise distribution

\begin{tabular}{|c|c|c|}
\hline \multirow{2}{*}{ Gender } & \multicolumn{2}{|c|}{ Trail Group } \\
\cline { 2 - 3 } & No. of Subjects & Percentage \\
\hline Male & 13 & $43.33 \%$ \\
\hline Female & 17 & $56.66 \%$ \\
\hline Transgender & 00 & $00 \%$ \\
\hline
\end{tabular}

Table 3: Prakriti wise distribution

\begin{tabular}{|c|c|c|}
\hline \multirow{2}{*}{ Deha prakruti } & \multicolumn{2}{|c|}{ Trial Group } \\
\cline { 2 - 3 } & No. of Sub & Percentage \\
\hline Vata-Pittaja & 1 & 3.33 \\
\hline Vata-kaphaja & 15 & 50 \\
\hline Kapha-Vataja & 14 & 46.66 \\
\hline Sannipataja & 0 & 0 \\
\hline
\end{tabular}

Table 4: Chronicity wise distribution

\begin{tabular}{|c|c|c|}
\hline \multirow{2}{*}{ Chronicity } & \multicolumn{2}{|c|}{ Trial Group } \\
\cline { 2 - 3 } & No. of Sub & \% \\
\hline 1-2 Years & 9 & 30 \\
\hline 2-3 Years & 10 & 33.33 \\
\hline 3-4 Years & 7 & 23.33 \\
\hline 4-5 Years & 4 & 13.33 \\
\hline
\end{tabular}

Table 5: Symptoms wise distribution

\begin{tabular}{|c|c|c|c|c|}
\hline S. No. & Symptom & Mild & Moderate & Severe \\
\hline $\mathbf{1}$ & Sandhishoola & 6 & 8 & 16 \\
\hline $\mathbf{2}$ & Sandhishotha & 1 & 12 & 17 \\
\hline $\mathbf{3}$ & Sandhistabdhata & 0 & 12 & 18 \\
\hline $\mathbf{4}$ & Angamarda & 4 & 20 & 6 \\
\hline $\mathbf{5}$ & Aruchi & 2 & 21 & 7 \\
\hline
\end{tabular}

\section{RESULTS}

Overall Relief Obtained in the study are taken under the heading of Results. All the 30 subjects registered completed the course of treatment of 16 days and a follow up of 30 days. The results thus obtained before treatment and after follow-up were analyzed statistically and are depicted as mentioned below.

Table 6: Effect of Erandamooladi niruha basti on Sandhishoola

\begin{tabular}{|c|c|c|c|c|c|c|c|}
\hline Subjective parameter & Phase & Mean & SD & SE & t - value (calculated) & $\mathbf{p}^{*}$ value & Remarks \\
\hline Sandhishoola & BT - AT & 2.53 & 0.937 & 0.171 & 14.81 & $\mathrm{p}<0.001$ & Highly Significant \\
\cline { 2 - 7 } & BT - AF & 3.9 & 1.125 & 0.205 & 18.99 & $\mathrm{p}<0.001$ & Highly Significant \\
\hline
\end{tabular}

Table 7: Effect of Erandamooladi niruha basti on Sandhi sthabdhata

\begin{tabular}{|c|c|c|c|c|c|c|c|}
\hline Subjective parameter & Phase & Mean & SD & SE & t - value (calculated) & p value $^{*}$ Remarks \\
\hline Sandhi Sthabdhata & BT - AT & 0.96 & 0.49 & 0.08 & 10.80 & p $<0.001$ & Highly Significant \\
\cline { 2 - 8 } & BT - AF & 1.93 & 0.63 & 0.11 & 16.55 & p $<0.001$ & Highly Significant \\
\hline
\end{tabular}

Table 8: Erandamooladi niruha basti on Aruchi

\begin{tabular}{|c|c|c|c|c|c|c|c|}
\hline Subjective parameter & Phase & Mean & SD & SE & t - value (calculated) & p $^{*}$ value & Remarks \\
\hline \multirow{2}{*}{ Aruchi } & BT - AT & 1.16 & 0.53 & 0.09 & 12.04 & $\mathrm{p}<0.001$ & Highly Significant \\
\cline { 2 - 7 } & BT - AF & 1.66 & 0.60 & 0.11 & 15.02 & $\mathrm{p}<0.001$ & Highly Significant \\
\hline
\end{tabular}

Table 9: Effect of Erandamooladi niruha basti on Angamarda

\begin{tabular}{|c|c|c|c|c|c|c|c|}
\hline Subjective parameter & Phase & Mean & SD & SE & t - value (calculated) & $\mathbf{p}^{*}$ value & Remarks \\
\hline Angamarda & BT - AT & 0.96 & 0.49 & 0.08 & 10.80 & p $<0.001$ & Highly Significant \\
\cline { 2 - 7 } & BT - AF & 1.6 & 0.62 & 0.11 & 14.10 & $\mathrm{p}<0.001$ & Highly Significant \\
\hline
\end{tabular}

Table 10: Effect of Erandamooladi niruha basti on Sandhi shotha

\begin{tabular}{|c|c|c|c|c|c|c|c|}
\hline Subjective parameter & Phase & Mean & SD & SE & t - value (calculated) & $\mathbf{p}^{*}$ value & Remarks \\
\hline \multirow{2}{*}{ Sandhi Shotha } & BT - AT & 0.7 & 0.53 & 0.09 & 7.16 & p $<0.001$ & Highly Significant \\
\cline { 2 - 8 } & BT - AF & 1.8 & 0.61 & 0.11 & 16.15 & p $<0.001$ & Highly Significant \\
\hline
\end{tabular}




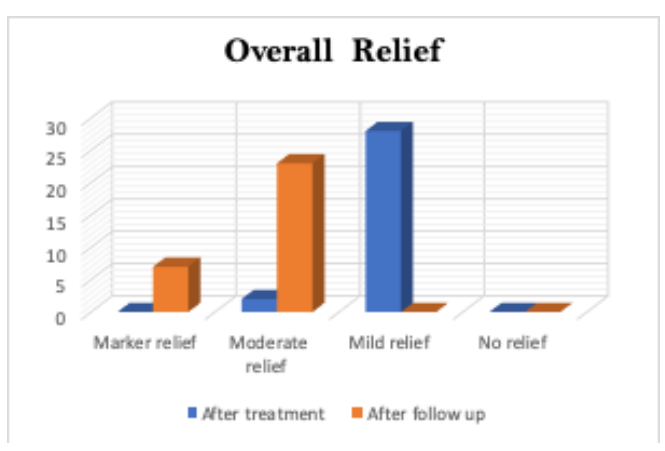

\section{DISCUSSION}

Amavata was selected for the research study keeping in mind the prevalence rate of the disease in the country. It is one of the most common disorder that has and is been affecting the human. And basti is the choice of treatment modalities accepted for Vataja diseases. The reason behind selecting Erandamooladi niruha basti was that, its importance has been mentioned by Yogaratnakara with a simile of the Lion and the Elephant. Just as the way the elephant can only be defeated by the King of the jungle, Lion, similarly Amavata can efficiently be treated with Eranda Prayoga. One of the basic and prime factors which exist in common between the individual and the universe is Panchamahabhoota. Though theoretically Panchamahabhoota is been given utmost importance, we hardly find any application of that practically. Hence, in the present study, an attempt has been made in relating to the Nidana, Lakshana and Samprapti of Amavata and its management to Panchamahabhootas and justifies the proven fact, i.e. Sarvam dravyam Panchabhoutikam.

\section{Age}

The disease Amavata can affect an individual at any age, but in the present study, mostly affected age group was between 31-50 years which shows that it mainly affects the middle-aged individuals.

\section{Gender}

Since the sample size taken was too small, we cannot depict the prevalence rate of Amavata based on gender.

\section{Deha prakriti}

Since the disease is of Vata Kapha pradhana, the subjects with vata kapha prakriti are more prone for the same. Hence maximum numbers of subjects registered were vata kapha prakriti.

\section{Chronicity}

Since the duration of the study was less, the chronicity less than 5 years was selected for the study. As the disease progressed, the subjects would have developed deformities of the phalanges, various upadravas would have been manifested.

\section{Sandhishoola}

In the present study, maximum number of subjects was registered with unbearable pain. It was because of the chronicity, continuous nidana sevana like avyayama and unhealthy/untimely eating habits. This increased the Vayu, Akasha and Prithvi mahabhoota.

\section{Sandhishotha}

This study shows that Sandhishotha is the prime factor bothering the subjects. A maximum number of subjects had severe sandhishotha due to vitiated Ama along with the pitta dosha. This is mainly of Prithvi and Agni mahabhoota pradhana

\section{Sandhistabdhata}

As that of shotha, Sandhistabdhata was also seen in maximum number of subjects in the present study. This was mainly due to the ama getting lodged in the Sandhis with the help of Vata leading to the loss of movements of the joints, which was of Prithvi and Jala mahabhoota.

\section{Angamarda}

This study shows that due to the presence of Ama there is feeling heaviness leading to Angamarda. This is mainly of Prithvi and Vayu mahabhoota pradhana.

In this present study, after treatment assessment, 00 subjects showed Marked Relief, 02 subjects showed Moderate Relief, 28 subjects showed Mild Relief and 00 subjects showed No Relief and after follow-up assessment, 07 subjects showed Marked Relief, 23 subjects showed Moderate Relief, 00 subjects showed Mild Relief and 00 subjects showed No Relief.

This study shows that the intervention of Panchamahabhoota at different levels, on different symptoms of a disease and with its management is possible with a thorough study. In the present study it was noticed that the Prithvi, Vayu and Agni mahabhoota of Erandamooladi niruha basti and Vayu, Agni and Akasha of Brihat Saindhavadhya Taila were proved to be efficiently working on the Prithvi, Jala, Vayu and Akasha mahabhoota of the disease Amavata.

\section{CONCLUSION}

Amavata as a disease finds its detailed description for the first time in the medieval period. Amavata is a chronic disease in nature and has an insidious onset. The role of Panchamahabhoota in the manifestation of Amavata can be easily analyzed and applied in other diseases also and managed efficiently as well. The statement that Sarvam dravyam Panchabhoutikam can actually be understood with further studies of various other diseases and their management. The role of Basti is found to be effective in all Vataja disorders, but it was witnessed well in the present study. Erandamooladi niruha basti and Brihat Saindhavadi taila Anuvasana basti has effectively worked on the patients of Amavata taken for the study. It can be concluded that the disease, which is of Prithvi, Jala, Vayu Mahabhoota pradhana due to various nidana, lakshana and samprapti, was efficiently managed with the drugs that were of Agni, Vayu and Akasha mahabhoota Pradhana.

\section{REFERENCES}

1. Madhavakara. Madhava Nidana. With Madhukosha Sanskrit commentary. Edited and Hindi translation by Narendranath shastri. Reprint edition. Varanasi: Motilal Banarasidas; $25^{\text {th }}$ adhyaya; 2009. p. 425.

2. Dr Namburi Hanumantha Rao, Panchabhoota Theory, Second edition, Choukhambha Krishnadas Academy, Varanasi, $13^{\text {th }}$ adhyaya; 2008. p. 123.

3. Sushruta, Sushruta Samhita, With the Nibandhasangraha commentary of Shri Dalhanacharya, Reprint edition, edited by Vaidya Jadavji Trikamji Acharya, Chaukhambha 
Orientalia, Varanasi, Sutrasthana, Chapter 42, Shloka 3; 2014. p. 184.

4. Agnivesha, Charaka, Dridhabala, Charaka Samhita Ayurvedadeepika commentary by Shri Chakrapnidatta. Edited by Vaidya Yadavji trikamji acharya. Reprint edition. Varanasi: Chaukhambha surbharati prakashan. Siddhisthana, $1^{\text {st }}$ adhyaya, $38^{\text {th }}-39^{\text {th }}$ shloka; 2012. p. 683.

5. Agnivesha, Charaka, Dridhabala, Charaka Saṃhita. Ayurvedadeepika commentary by Shri Chakrapnidatta. Edited by Vaidya Yadavji trikamji acharya. Reprint edition. Varanasi: Chaukhambha surbharati prakashan. Siddhisthana, $1^{\text {st }}$ adhyaya, $38^{\text {th }}-39^{\text {th }}$ shloka; 2012. p. 683.

6. Agnivesha, Charaka, Dridhabala, Charaka Saṃita. Ayurvedadeepika commentary by Shri Chakrapnidatta. Edited by Vaidya Yadavji trikamji acharya. Reprint edition. Varanasi: Chaukhambha surbharati prakashan. Sutrasthana, $1^{\text {st }}$ adhyaya, $4^{\text {th }}-5^{\text {th }}$ shloka; 2012. p. 5 .

7. Madhavakara. Madhava Nidana. With Madhukosha Sanskrit commentary. Edited and Hindi translation by Narendranath shastri. Reprint edition. Varanasi: Motilal Banarasidas; $25^{\text {th }}$ adhyaya; 2009. p. 424.
8. Madhavakara. Madhava Nidana. With Madhukosha Sanskrit commentary. Edited and Hindi translation by Narendranath shastri. Reprint edition. Varanasi: Motilal Banarasidas; $25^{\text {th }}$ adhyaya; 2009. p. 426.

9. Madhavakara. Madhava Nidana. With Madhukosha Sanskrit commentary. Edited and Hindi translation by Narendranath shastri. Reprint edition. Varanasi: Motilal Banarasidas; $25^{\text {th }}$ adhyaya; 2009. p. 424.

10. Chakrapanidatta. Chakradatta-Chikitsa sangraha. English translation by Dr. G Prabhakar Rao. Varanasi: Chaukhambha Orientalia; $25^{\text {th }}$ adhyaya, $1^{\text {st }}$ shloka; 2014. p. 264.

\section{Cite this article as:}

Parinita S G et al. Analysis of Panchamahabhoota Siddhanta with special reference to Amavata and its management through Erandamooladi Niruha Basti: A Clinical Study. Int. J. Res. Ayurveda 2020;11(1):60-64 http://dx.doi.org/10.7897/2277-4343.110112

Disclaimer: IJRAP is solely owned by Moksha Publishing House - A non-profit publishing house, dedicated to publishing quality research, while every effort has been taken to verify the accuracy of the content published in our Journal. IJRAP cannot accept any responsibility or liability for the site content and articles published. The views expressed in articles by our contributing authors are not necessarily those of IJRAP editor or editorial board members. 